УДК 342.9

DOI https://doi.org/10.32844/2618-1258.2019.5-2.24

КРАСНОБОРОВА М.П.

\title{
КАДРОВЕ ЗАБЕЗПЕЧЕННЯ СПІЛЬНИХ СЛІДЧИХ ГРУП, СТВОРЕНИХ У МЕЖАХ МІЖНАРОДНОГО СПІВРОБІТНИЦТВА ПІД ЧАС КРИМІНАЛЬНОГО ПРОВАДЖЕННЯ
}

У статті здійснено аналіз діяльності спільних слідчих груп у рамках міжнародного співробітництва під час кримінального провадження в контексті участі в них представників компетентних органів держав-учасниць спільної слідчої групи та інших інституцій.

Проведення спільних розслідувань складних транснаціональних злочинів представниками компетентних органів різних держав $є$ відносно новим інструментом міжнародної співпраці, який потребує грунтовного вивчення. Ця стаття покликана висвітлити кадрове забезпечення спільних слідчих груп, повноважень їі членів та учасників, їх взаємодію при проведенні спільних слідчих дій. Зокрема, надано детальну характеристику керівника спільної слідчої групи, його ролі та статусу. Так, керівником спільної слідчої групи є представник компетентного органу, уповноваженого здійснювати досудове розслідування кримінальних проваджень, держави-сторони спільної слідчої групи, під керівництвом якого члени спільної слідчої групи виконують свої завдання у конкретний період часу під час перебування на території держави, в якій працює спільна слідча група.

Автором з'ясовано повноваження членів спільної слідчої групи, якими здебільшого $є$ представники правоохоронних органів, що здійснюватимуть слідчі дії та оперативні заходи при проведенні спільних слідчих дій, а також залежно від національного законодавства сторін спільної слідчої групи прокурори та слідчі судді.

У статті висвітлено поняття «відряджених членів спільної слідчої групи», тобто набуття членами спільної слідчої групи відповідного статусу в разі, коли вони перебувають та беруть участь у розслідуванні за межами своєї держави, їхню відповідальність за вчинення протиправних дій на території держави відрядження.

Окреслено можливості для участі як учасників спільних слідчих груп інституцій Європейського Союзу, насамперед Євроюсту, Сврополу та OLAF, а також питання залучення до проведення спільних розслідувань експертів, перекладачів та інших фахівців, які не є працівниками правоохоронних держав-сторін спільної слідчої групи.

Ключові слова: спільна слідча група, керівник спільної слідчої групи, член спільної слідчої групи.

The article analyzes the activities of joint investigation teams during international cooperation in criminal matters in the context of the participation of representatives of the competent authorities of the parties to the joint investigation team and from other institutions.

Joint investigations of complex transnational crimes by the representatives of the competent authorities of different countries are a relatively new instrument of international cooperation that needs a thorough study. This article is intended to highlight the staff of joint investigation teams, the powers of its members and participants, their interaction in conducting joint investigative activities.

(C) КРАСНОБОРОВА М.П. - радник (Посольство України в Королівстві Нідерланди), прокурор зі зв'язку (Свропейська організація з питань юстиції), здобувач (Міжрегіональна академія управління персоналом) 
Also, a detailed description of the joint investigation team's leader, his role and status is provided. Thus, the joint investigation team's leader is a representative of the competent pre-trial investigation authority of the state party to the joint investigation team, under the guidance of which members of the joint investigation team perform their tasks during a specific period of time while staying at the territory of the state in which the joint investigative team acts.

The author clarifies the powers of the joint investigative team's members, who in most cases are the representatives of law enforcement agencies, which will carry out investigative actions and operational measures, as well as prosecutors and investigative judges, depending on the national legislation of the joint investigative team's state parties. The article covers the notion of "seconded members of a joint investigation team", namely the acquisition of appropriate status by the joint investigation team's members when they are staying and involved in the investigation activities outside their own country, their responsibility in the case of committing illegal activities in the territory of the another state.

Possibilities for participation of the institutions of the European Union, first of all Eurojust, Europol and OLAF, as participants in joint investigation teams, as well as the issue of involvement of experts, translators and other specialists, who are not employees of the law-enforcement of the parties to joint investigation team agreement, in joint investigations are also outlined.

Key words: joint investigation team, international cooperation in criminal matters, JIT leader, JIT member.

Вступ. Розвиток технологій, сучасні економічні та політичні процеси зумовлюють нові виклики у боротьбі з транснаціональною організованою злочинністю. Ратифікація Україною низки міжнародних договорів, які зокрема регламентують питання міжнародного співробітництва під час кримінального провадження при розслідуванні таких видів злочинів, насамперед Конвенцій Організації Об'єднаних Націй проти транснаціональної організованої злочинності та проти корупції, Другого додаткового протоколу до Європейської конвенції про взаємну допомогу у кримінальних справах, дала змогу українським компетентним органам здійснювати розслідування транскордонних кримінальних правопорушень спільно з представниками правоохоронних органів інших держав. Водночас така діяльність потребує грунтовного вивчення, зокрема в частині регламентування адміністративно-правових функцій уповноважених осіб, які беруть участь у діяльності спільних слідчих груп.

Аналіз останніх публікацій і досліджень. Поняття спільних слідчих груп у контексті міжнародного співробітництва під час кримінального провадження з'явилося відносно недавно та було зумовлене ситуацією, яка склалася навколо взаємодії між правоохоронними та судовими органами різних країн при розслідуванні складних злочинів 3 інтернаціональним складником. У вітчизняних наукових колах вказане питання мало досліджене. Окремі питання вивчалися Ю.М. Чорноус, Н.В. Конограй.

3 іноземних дослідників зазначене питання грунтовно опрацьовано Конні Райкен, дослідником і лектором Університету Тілбур (Королівство Нідерланди), Гертом Вермейленом, професором кримінального права в Університеті Генту (Королівство Бельгія), болгарськими вченими Маріном Петковим і Драгоміром Крастевим.

Постановка завдання. Метою статті є висвітлення ролі, повноважень і функцій осіб, які беруть участь у роботі спільних слідчих груп, особливості повноважень керівника, членів та учасників спільної слідчої групи.

Результати дослідження. 3 метою прискорення взаємодії у рамках міжнародного співробітництва під час кримінального провадження між правоохоронними та судовими органами різних держав використовується механізм діяльності спільних слідчих груп, передбачений низкою міжнародних багатосторонніх договорів.

Спільна слідча група - це міжнародна група, утворена за взаємною згодою компетентних органів двох або більше держав для проведення кримінальних розслідувань в одній або декількох державах, що створюють таку групу з певною метою і на певний період. Склад спільної слідчої групи визначається в угоді про створення спільної слідчої групи, тобто в письмовому договорі між двома або більше країнами чи уповноваженими інституціями, на основі якого в подальшому функціонуватиме відповідна спільна слідча група, і $є$ іiї важливим елементом. 
Так, у статті 20 Другого додаткового протоколу до Європейської конвенції про взаємну допомогу у кримінальних справах від 8 листопада 2001 року визначається, що укладення угоди про спільну слідчу групу ініціюється шляхом направлення відповідного запиту про створення спільної слідчої групи однією із зацікавлених держав. У запиті про створення спільної слідчої групи, окрім традиційних для клопотання про міжнародну правову допомогу відомостей про назву органу, який звертається із проханням, предмет і причину прохання, відомостей про особу і іiі громадянство, дані про правопорушення і стислий виклад фактів, повинні міститися пропозиції стосовно складу групи [5].

Спільна слідча групи створюється між компетентними органами принаймні двох держав. На практиці не рідкість, коли спільні слідчі групи створюються між більшою кількістю сторін, що зумовлюється полегшенням обміну інформацією та доказами. Відповідно до усталеної практики кожна сторона угоди про створення спільної слідчої групи призначає таких осіб:

1) керівника чи керівників спільної слідчої групи, відповідальних, зокрема, за нагляд за діяльністю спільної слідчої групи, коли вона здійснює свою діяльність на території відповідної держави;

2) членів спільної слідчої групи, якими здебільшого є представники правоохоронних органів, що здійснюватимуть слідчі дії та оперативні заходи, а також прокурори та слідчі судді.

Якщо будь-яка із зазначених осіб не зможе виконати свої обов'язки, ій призначається заміна. При цьому письмове повідомлення про таку заміну надається всім зацікавленим сторонам і додається до угоди.

Керівниками групи є представники компетентних органів уповноважених на здійснення досудового розслідування кримінальних проваджень, під керівництвом яких члени спільної слідчої групи виконують свої завдання в державі, де вона діє у конкретний період часу. Керівник спільної слідчої групи діє в межах своєї компетенції відповідно до національного законодавства і відповідає за керівництво розслідуванням і нагляд за діяльністю інших членів спільної слідчої групи.

При визначенні особи та професійної належності керівника спільної слідчої групи визначальну роль має національне законодавство. У міжнародних договорах немає визначення чи керівник спільної слідчої групи повинен бути прокурором, слідчим суддею чи представником правоохоронного (слідчого) органу такого як поліція, органи безпеки, фіскальні органи.

Оскільки спільні слідчі групи зазвичай розглядаються як «особлива» форма взаємної правової допомоги, а процесуальне керівництво досудовим розслідуванням здійснюється прокурорами або в деяких юрисдикціях слідчими суддями, доцільно, щоб саме вони були визначені керівниками відповідної слідчої групи. Наприклад, роль керівника спільної слідчої групи в Болгарії може виконувати прокурор, який здійснює нагляд за досудовим розслідуванням [13].

В окремих випадках може бути доречним, щоб керівником спільної слідчої групи було визначено працівника слідчого органу, наприклад у випадку необхідності здійснення значної кількості оперативно-розшукових і слідчих дій. У таких випадках на практиці визначають двох керівників: одного прокурора, іншого - представника слідчого органу. Також з існуючих положень щодо спільних слідчих груп можна зробити висновок про те, що принаймні один керівник спільної слідчої групи повинен бути призначений від кожної 3 держави-сторони спільної слідчої групи. На практиці так здебільшого і відбувається.

Ускладнення також можуть виникнути, коли злочини, які розслідує спільна слідча група, $\epsilon$ предметом декількох пов'язаних розслідувань, що проводяться в межах однієї держави різними правоохоронними органами. Ця ситуація може потенційно вплинути на ефективність роботи спільної слідчої групи, якщо такі органи не мають однакової позиції щодо розслідування. Враховуючи викладене, координація взаємопов'язаних розслідувань повинна бути забезпечена на національному рівні до створення спільної слідчої групи таким чином, щоб для кожної відповідної держави-учасниці було призначено лише одного керівника.

У разі, коли члени спільної слідчої групи перебувають та беруть участь у розслідуванні за межами своєї держави, вони отримують статус «відряджених членів спільної слідчої групи». Наявність відряджених членів значно сприяє розслідуванню, оскільки вони можуть надати допомогу членам спільної слідчої групи держави перебування, які виконують слідчі дії, наприклад шляхом надання порад, допомоги у перекладі та спілкуванні зі свідками, обміну спеціальними методиками. Все це дозволяє відрядженим членам брати активну роль у розслідуванні.

У разі наявності відповідних положень у національному законодавстві держави перебування спільна слідча група надає їм можливість особисто збирати докази способом, найбільш відповідним для потреб національного розслідування та майбутнього судового розгляду. Це особли- 
во корисно при допиті свідків, оскільки відповідь на запитання свідка може призвести до нового запитання, яке буде негайно задане відрядженим членом спільної слідчої групи, що було б неможливим, якби допит проводився через традиційні механізми міжнародної правової допомоги.

На практиці існують різні форми діяльності спільних слідчих груп, що підтверджує гнучкість цього інструменту та його здатність адаптуватися до конкретних потреб кримінального провадження. Наприклад, часто розслідування проводяться спочатку паралельно різними залученими державами, при цьому здійснюється періодичний обмін зібраними доказами. На наступному етапі члени спільної слідчої групи відряджаються кожною державою для підтримки узгодженої операційної фази.

Безумовно, що основною ідеєю спільної слідчої групи є функціонування групи слідчих i прокурорів із держав-учасниць, які спільно працюють і проводять розслідування. Для відряджених членів не обов'язково бути присутніми під час розслідування, оскільки це їх право, а не обов'язок. Крім того, якщо відрядженого члена немає під час слідчих заходів, це жодним чином не впливає на обгрунтованість таких заходів або законність зібраних доказів.

Немає жодної вимоги, щоб член спільної слідчої груп працював за межами своєї країни, навіть якщо спільна слідча група постійно знаходиться в іншій країні. Спільна слідча група може бути належним чином сформованою із представників двох або більше держав, жоден із яких не працює за межами своєї країни. Наприклад Албанія та Північна Македонія могли б погодитися на функціонування спільної слідчої групи, яка базується в Скоп'є, з одним учасником албанцем, який проводить розслідування в Тирані, але ніколи не буває в Скоп’є. Аналогічно кілька членів можуть складати групу, зібрану в одному «штабі», тоді як решта членів діють у своїх країнах. 3 огляду на витрати та зобов'язання, необхідні для відрядженого персоналу за кордоном, такий тип домовленостей може виявитися привабливим для сторін [14].

Міжнародне законодавство також регламентує такі важливі питання, пов'язані з роботою спільної слідчої групи, як кримінальну та цивільну відповідальність відряджених членів. Відповідно до статті 15 Конвенції про взаємодопомогу в кримінальних справах між державами-членами Свропейського Союзу від 12 липня 2000 року вони «вважаються посадовою особою держави-члена операції стосовно правопорушень, вчинених проти них або ними» [4].

Наприклад, якщо відряджений член А. вчинить вбивство в Болгарії, він / вона буде нести відповідальність за вбивство із кваліфікуючими обставинами. Стосовно цивільно-правової відповідальності відряджених членів стаття 16 Конвенції зазначає, що «посадові особи однієї держави-члена діють в іншій державі-члені, перша держава-член несе відповідальність за будь-яку шкоду, заподіяну ними під час своєї діяльності, відповідно до законодавства держави-члена, на території якої вони працюють». Тобто держава-член А. несе відповідальність за дії відрядженого члена А. на території держави-члена В. відповідно до законодавства останньої [13].

Як і в національних розслідуваннях для діяльності спільної слідчої групи важливою $\epsilon$ участь осіб, які не $\epsilon$ представниками правоохоронних чи судових органів (експертів, перекладачів, технічних спеціалістів). Відповідні питання щодо умов та обставин їх залучення повинні бути обговорені сторонами при укладенні угоди про створення спільної слідчої групи. Крім сторін, до участі у спільній слідчій групі можуть залучатися представники інших органів чи інституцій, зазвичай йдеться про спеціалізовані агенції ЄC (Євроюст, Європол та OLAF). Деталі щодо їх участі містяться у спеціальному додатку до угоди про створення спільної слідчої групи, зразок якого можна знайти в типовій угоді про ії створення. Загалом таким представникам учасників спільної слідчої групи не надається право бути присутніми під час виконання або виконувати слідчі заходи. Їхнє основне завдання - це сприяння та покращення координації між членами спільної слідчої групи та обмін досвідом і кращими практиками.

Висновки. Кадрове забезпечення спільних слідчих груп є одним із ключових факторів, які визначають ефективність проведення спільних розслідувань. Із ключових принципів діяльності спільної слідчої групи у контексті повноважень їі членів можна узагальнити такі:

1) діяльність спільної слідчої групи проводиться відповідно до законодавства держави, в якій вона працює, та під наглядом керівника спільної слідчої групи, призначеного цією державою;

2) відряджені члени мають право бути присутніми під час розслідування, якщо тільки керівник спільної слідчої групи держави перебування не вирішить інакше за наявності на те підстав;

3) керівником спільної слідчої групи може бути доручено відрядженим членам здійснювати слідчі заходи за згодою держави, де діє спільна слідча група, та держави, яка їх відрядила; 
4) відряджені члени мають право ділитися зі спільною слідчою групою інформацією, наявною у держави, яка їх відрядила. В разі виникнення підстав вони можуть ініціювати розслідування у державі перебування відповідно до умов, передбачених їі національним законодавством.

\section{Список використаних джерел:}

1. Конвенція Організації Об'єднаних Націй про боротьбу проти незаконного обігу наркотичних засобів і психотропних речовин від 20 грудня 1988 року. URL: https://www.unodc.org/pdf/ convention 1988 ru.pdf (дата звернення: 07.03.2019).

2. Конвенція Організації Об'єднаних Націй проти транснаціональної організованої злочинності від 15 листопада 2000 року. URL: https://www.un.org/ru/documents/decl_conv/conventions/ orgcrime.shtml (дата звернення: 07.03.2019).

3. Конвенція Організації Об'єднаних Націй проти корупції від 31 жовтня 2003 року. URL: https://zakon.rada.gov.ua/laws/show/995_c16 (дата звернення: 25.05.2019).

4. Конвенція про взаємодопомогу в кримінальних справах між державами-членами Європейського Союзу від 12 липня 2000 року. URL: https://zakon.rada.gov.ua/laws/show/994_238 (дата звернення: 21.01.2019).

5. Другий додатковий протокол до Європейської конвенції про взаємну допомогу у кримінальних справах від 8 листопада 2001 року. URL: https://zakon.rada.gov.ua/laws/show/994_518 (дата звернення: 21.01.2019).

6. Закон України «Про ратифікацію Другого додаткового протоколу до Європейської конвенції про взаємну допомогу у кримінальних справах» від 01.06.2011. URL: https://zakon.rada.gov.ua/ laws/show/3449-17 (дата звернення: 21.01.2019).

7. Кримінальний процесуальний кодекс України URL: https://zakon.rada.gov.ua/laws/ show/994 518 (дата звернення: 23.01.2019).

8. Угода про співробітництво між Україною та Європейською організацією з питань юстиціï. URL: https://zakon.rada.gov.ua/laws/card/984_024-16 (дата звернення: 23.01.2019).

9. C. Rijken, G. Vermeulen (Eds.). Joint Investigation Teams in the European Union 2006, TMC Asser press, The Hague, The Netherlands and the Authors, $248 \mathrm{p}$.

10. Joint Investigation Teams Practical Guide, Council of the European Union, No. prev. doc.: 11501/16. URL: http://www.eurojust.europa.eu/doclibrary/JITs/JITs\%20framework/JITs\% 20Practical\%20Guide/JIT-GUIDE-2017-EN.pdf (дата звернення: 23.01.2019).

11. Council Resolution on a Model Agreement for Setting Up a Joint Investigation Team (JIT), 2017/C 18/01, the Council of the European Union. URL: http://www.eurojust.europa.eu/ doclibrary/JITs/JITs\%20framework/Model\%20Agreement\%20for\%20setting\%20up\%20a\%20Joint\% 20Investigation\%20Team/JIT-2017-MODEL-EN.pdf (дата звернення: 23.01.2019).

12. Guidelines and model agreement on JIT. URL: https://rm.coe.int/CoERMPublicCommon SearchServices/DisplayDCTMContent?documentId=09000016806a3dfc (дата звернення: 23.01.2019).

13. Krasimira Ipokratova, Maya Kirirlova, Gospodin Bumbarov, Rumyana Tozova, Using the Joint Investigation Team as a Legal Tool for Investigating Human Trafficking for Sexual Exploitation within the EU. URL: http://www.ejtn.eu/PageFiles/17290/WR\%20TH-2018-01\%20BG.pdf (дата звернення: 07.06.2019).

14. Trafficking in Persons \& Smuggling of Migrants Guidelines on International Cooperation. URL: https://www.un.org/ruleoflaw/files/UNODC\%20Trafficking\%20in\%20Persons\%20and\% 20Smuggling\%20of\%20Migrants\%20Guidelines.pdf (дата звернення: 07.06.2019). 